\title{
ISOLATION, CHARACTERIZATION AND ANTIDIABETIC ACTIVITY OF PHENOLIC COMPOUNDS ISOLATED FROM Macaranga magna TURRILL
}

\author{
Minarti $^{1,2}$, A.H. Cahyana ${ }^{1}$ and A. Darmawan ${ }^{2, \bowtie}$ \\ ${ }^{1}$ Department of Chemistry, University of Indonesia, Depok, West Java, Indonesia, 16424 \\ ${ }^{2}$ Research Center for Chemistry, Indonesian Institute of Sciences, Tangerang Selatan, Banten, \\ Indonesia, 15314 \\ ${ }^{\square}$ Corresponding Author: ahmaddarmawan2013@gmail.com
}

\begin{abstract}
Southeast Sulawesi is an Indonesian region that has a large amount of biodiversity resources. As part of our continuous drug discovery project, three phenolic compounds, namely (1) scopoletin, (2) apigenin, and (3) gallic acid were successfully isolated from the leaf extract of Macaranga magna Turrill. The isolation and purification processes were conducted by serial chromatography, and their chemical structures were elucidated on the basis of spectroscopic data (FT-IR, FT-NMR and LC-ESI-MS), as well as through data comparison with the related body of literature. Their potential antidiabetic activity was evaluated against $\alpha$-glucosidase enzymes. Scopoletin showed the highest antidiabetic activity compared to apigenin and gallic acid, with $\mathrm{IC}_{50}$ values of $91.7,28.3$, and $198.5 \mu \mathrm{g} / \mathrm{mL}$, respectively.
\end{abstract}

Keywords: Scopoletin, Apigenin, Gallic Acid, Macaranga magna Turrill, $\alpha$-glucosidase, Antidiabetic

RASĀYAN J. Chem., Vol. 14, No.4, 2021

\section{INTRODUCTION}

As a megabiodiversity country, Indonesia has diverse biodiversity, especially in terms of plant species. However, there remain many plant species that have not yet been explored and utilized. ${ }^{1}$ Macaranga (Euphorbiaceae) known in Indonesia as 'mahang-mahangan,' is a large genus of plant with over 300 species and is widely distributed to Africa, Madagascar, Asia, Australia, and the Pacific islands. ${ }^{2-5}$ Macaranga species have an important role in traditional medicine systems to treat certain diseases due to their bioactive compounds such as Macaranga gigantea and M. triloba, which have been used to treat fungal infections, leaf decoction, stomachaches ${ }^{2,6}$, Macaranga hypoleuca can be used as a febrifuge, expectorant and antispasmodic, and has antioxidant and anti-bacterial properties. ${ }^{6} \mathrm{M}$. denticulata has been used to treat icteric hepatitis ${ }^{7} ; M$. indica has been used to treat anemia and tumors in India and Bangladesh $^{2,6} ; M$. peltala has been used to treat relief from venereal sores and has antioxidant, antimicrobial and cytotoxicity activity ${ }^{7} ; M$. hurifolia Beille has been used to treat cough and diabetes, to relieve oedema in pregnant women and as a purgative ${ }^{8}$; and M. barteri Müll.-Arg has been used as an antioxidant, anti-inflammatory and anti-hyperalgesic, and has also been reported to relieve persistent cough, bronchitis, stomatitis, gastric ulcers, dysentery, swelling and arthritis. ${ }^{9}$ Previous studies showed that the Macaranga genus is a source for various phenolic compounds such as flavonoids ${ }^{2,3,9-20,25}$ and stilbenes. ${ }^{8,15,21-23}$

Previous phytochemical studies on the Macaranga genus have shown that this genus is a source for various and unique bioactive compounds such as apigenin, apigenin-8-C-glycoside and scopoletin from M. gigantifolia ${ }^{2,7,16}$, 6,8-diprenyl-4'-methyl-naringenin, 4'-deprenyl-4-methoxymappain, 4'-methyl-8prenyltaxifolin from $M$. balansae ${ }^{24}$, macatanarin $\mathrm{D}$, schweinfurthin $\mathrm{H}$, vedelianin, schweinfurthin $\mathrm{F}$, schweinfurthin, 4'deprenyl-mappain from $M$. $\operatorname{tanarius}^{5,22}$ as a cytotoxic active compound, glyasperin A from M. gigantea and M. pruinosa as an antioxidant. ${ }^{25-26}$ Nymphaeol C, solophenol D, nymphaeol A, and

Rasayan J. Chem., 14(4), 2420-2427(2021)

http://doi.org/10.31788/RJC.2021.1446290

This work is licensed under a CC BY 4.0 license. 
RASĀYAN J. Chem.

Vol. 14 | No. 4 |2420-2427| October- December | 2021

nymphaeol B were isolated from the ethyl acetate fraction of $M$. tanarius leaves as antiplasmodial active compounds. Varyophyllene, neophytadiene, $\alpha$-humulene, phytol, ethyl-ester hexadecanoic acid ${ }^{18}$, and nerolidol from M. barteri were isolated as antimicrobes. Macatrichocarpins A-D, oxymacatrichocarpin C, and isomacatrichocarpin from $M$. tricocharpa were isolated as antibacterial agents. ${ }^{27}$

Diabetes mellitus is a metabolic disease caused by a decrease in insulin secretion or insulin sensitivity. Indonesia has become one of the highest diabetes prevalent countries in the world, and it has been estimated that 21.3 million people will have diabetes by $2030 .{ }^{27}$ Inhibiting the activity of the enzyme will delay the absorption of the glucose, and the levels of blood glucose will decrease as a result. ${ }^{29}$ Due to the prevalence of diabetes, the exploration and utilization of natural products as resources to treat diabetes is the primary aim of this research.

Macaranga magna Turrill belongs to the Macaranga genus, which has not been explored intensively. As far as our knowledge, the phytochemical study of M. magna was only reported by Minarti et al. ${ }^{29}$ As part of our continued studies of drug discovery projects from Indonesian natural products resources, we explored the secondary metabolites compound content of the leaves of M. magna Turrill and evaluated their biological activity as $\alpha$-glucosidase inhibitory activity.

\section{Material and Methods}

\section{EXPERIMENTAL}

Macaranga magna Turrill. Leaves were collected from Mekongga Forest, District Kolaka, Southeast Sulawesi. Plant species identification was performed by Herbarium Bogoriense, Research Center for Biology, Indonesian Institute of Sciences, Indonesia. Distilled technical grade organic solvents of $n$ hexane, ethyl acetate, and methanol were used for extraction, fractionation, isolation and purification. Silica gel $60(0.063-0.200 \mathrm{~mm})$ (Merck, 1.07734.1000) and TLC plate (Silica gel 60 F254) (Merck, 1.05554.0007) were used for isolation and chemical compounds spot identification. Instrumentation analysis of the isolated compounds used chloroform- $d$ (Merck, 1.02450.0100), methanol- $d_{4}$ (Cambridge Isotope Laboratories. Inc., DLM-24-50), and acetone- $d_{6}$ (Cambridge Isotope Laboratories. Inc., DLM-925) for NMR (JEOL NMR ECZ500R $500 \mathrm{MHz}$ ) analysis; and methanol hypergrade (Merck, 1.06035.2500) and acetonitrile hypergrade (Merck, 1.00039.2500) for LC-MS/MS (Waters, Xevo G2-XS QTOF) analysis. A spectrophotometer (Agilent Technologies, Cary $60 \mathrm{UV}-\mathrm{Vis}$ ) was used for maximum wavelength analysis, FTIR (Shimadzu, IR Prestige-21) for the determination of chemical groups, and a melting point meter (Fisher Scientific and KRUSS, M5000). p-NPG (Wako 351-17473, Osaka, Japan) and a-glucosidase enzyme from yeast (Wako 46511003, Osaka, Japan) were used for the determination of $\alpha$-Glucosidase inhibitory activity.

\section{Extraction and Isolation}

Dried and powdered M. magna Turrill leaves were macerated with distilled methanol to obtain methanol extract. The methanol extract was further fractionated with $n$-hexane, ethyl acetate, acetone and $n$ butanol. About $4.2 \mathrm{~g}$ of ethyl acetate fraction was subjected to silica gel column chromatography and eluted using mobile phase gradient system solvent, which started from $n$-hexane, ethyl acetate and methanol, to obtain 11 sub-fractions. Sub-fraction 4 (SFea-4) and SFea-7 were subjected to silica gel column chromatography using a gradient system solvent from $n$-hexane and ethyl acetate to methanol, which led to the isolation of compounds $\mathbf{1}$ and 2. The isolation and purification process of $9.9 \mathrm{~g}$ of acetone fraction used silica gel column chromatography with the same system solvent of the mobile phase, which led to the isolation of compound $\mathbf{3}$, obtained from the recrystallization process using chloroform: methanol (1:1) of sub-fraction 7 (SFac-7).

Compound 1: pale yellow powder, mp. $202-204{ }^{\circ} \mathrm{C}$, UV $\lambda \underset{\max }{\mathrm{MeOH}} 298,345$. FTIR (KBr) Vmax $\left(\mathrm{cm}^{-1}\right)$ 3228, 2924, 1711, 1610, 1176. LC-ESI-MS m/z $193[\mathrm{M}+\mathrm{H}]^{+} .{ }^{1} \mathrm{H}-\mathrm{NMR}\left(500 \mathrm{MHz}\right.$, in Acetone- $\left.d_{6}\right)(\delta$ ppm) $6.17(1 \mathrm{H}, d, J=9.5 \mathrm{~Hz}, \mathrm{H}-2), 6.78(1 \mathrm{H}, s, \mathrm{H}-8), 7.18(1 \mathrm{H}, s, \mathrm{H}-5), 7.83(1 \mathrm{H}, d, J=9.5, \mathrm{H}-3), 3.89$ $\left(3 \mathrm{H}, s,-\mathrm{OCH}_{3}\right) .{ }^{13} \mathrm{C}-\mathrm{NMR}\left(125 \mathrm{MHz}\right.$, in Acetone- $\left.d_{6}\right)(\delta \mathrm{ppm}) 56.7\left(-\mathrm{OCH}_{3}\right), 112.1(\mathrm{C}-10), 109.9(\mathrm{C}-5)$, 146.0 (C-6), 151.9 (C-7), 103.7 (C-8), 151.2 (C-9), 113.3 (C-3), 144.7 (C-4). 
RASĀYAN J. Chem.

Vol. 14 | No. 4 |2420-2427| October- December | 2021

Compound 2: yellowish-green powder, mp. $345-347^{\circ} \mathrm{C}$, UV $\lambda_{\max }^{\mathrm{MeOH}} 273 \& 338$. FTIR (KBr) Vmax (cm ${ }^{-}$ $\left.{ }^{1}\right) 3246,1654,1570$. LC-ESI-MS m/z $271.2[\mathrm{M}+\mathrm{H}]^{+}$. ${ }^{1} \mathrm{H}-\mathrm{NMR}(\mathrm{DMSO}, 500 \mathrm{MHz})(\delta \mathrm{ppm}) \delta_{\mathrm{H}} 6,75(1 \mathrm{H}$, s); $6,15(1 \mathrm{H}, \mathrm{d}, J=1,95 \mathrm{~Hz}) ; 6,44(1 \mathrm{H}, \mathrm{d}, J=1,95 \mathrm{~Hz}) ; 7,91(2 \mathrm{H}, \mathrm{d}, J=9,05 \mathrm{~Hz}) ; 6,90(2 \mathrm{H}, \mathrm{d}, J=9,05 \mathrm{~Hz})$; $12,94(-\mathrm{OH}) .{ }^{13} \mathrm{C}-\mathrm{NMR}\left(125 \mathrm{MHz}\right.$, in DMSO, ) $\delta_{\mathrm{C}} 163,7 ; 102,8 ; 181,7 ; 161,3 ; 99,0 ; 164,6 ; 94,1 ; 157,4$; 103,$6 ; 121,2 ; 128,5$ (2C); 116,0 (2C), 161,5.

Compound 3: white powder, mp. $250-252{ }^{\circ} \mathrm{C}$, UV $\lambda \underset{\max }{\mathrm{MeOH}}$ 272. FTIR (KBr) Vmax $\left(\mathrm{cm}^{-1}\right) 3282,1701$, 1618, 1440, 1315, 1031, 862, 711. LC-ESI-MS m/z 170, ${ }^{1} \mathrm{H}-\mathrm{NMR}\left(500 \mathrm{MHz}\right.$, in methanol- $\left.d_{4}\right) 7.05(2 \mathrm{H}$, s). ${ }^{13} \mathrm{C}-\mathrm{NMR}\left(125 \mathrm{MHz}\right.$, in methanol- $\left.d_{4}\right) 122.0$ (C-1), 110.4 (C-2/C-6), 146.5 (C-3/C-5), 139.7 (C-4), and $170.5(\mathrm{C}-7)$.

\section{$\alpha$-Glucosidase Inhibitory Activity}

A-glucosidase inhibitory activity of isolated compounds was conducted using $\alpha$-Glucosidase inhibitory activity methods developed by Dewi ${ }^{30}$. About $250 \mu \mathrm{L}$ of $\alpha$-Glucosidase $(0.124$ unit $/ \mathrm{mL}), 495 \mu \mathrm{L}$ of $0.1 \mathrm{M}$ phosphate buffer (pH 7.0), and $5 \mu \mathrm{L}$ of various concentrations of samples in DMSO $(50-200 \mu \mathrm{g} / \mathrm{mL})$ were pre-incubated at $37^{\circ} \mathrm{C}$ for 5 minutes. The addition of $250 \mu \mathrm{L}$ of $5 \mathrm{mM} p$-NPG was used for the initiation reaction. The mixtures were further incubated at $37{ }^{\circ} \mathrm{C}$ for 15 minutes. The reaction was stopped by the addition of $1 \mathrm{~mL}$ of $0.1 \mathrm{M} \mathrm{Na}_{2} \mathrm{CO}_{3}$. $\alpha$-Glucosidase inhibitory activity was determined by the measuring of the $p$-NPG released using a spectrophotometer at $\lambda 410 \mathrm{~nm}$.

\section{RESULTS AND DISCUSSION}

Macaranga plants are known as a resource for unique biologically active compounds, especially phenolic compounds. In this study, we have successfully isolated three phenolic compounds from ethyl acetate fraction and acetone fraction, and one sterol compound from ethyl acetate fraction.

Compound 1 was obtained as a pale-yellow powder with a melting point of $202-204{ }^{\circ} \mathrm{C}$. The UV-Visible spectrum of compound 1 showed typical maximum absorption bands of scopoletin at 298 and $345 \mathrm{~nm}$, indicating that compound $\mathbf{1}$ has unsaturated constituents which form a conjugated bond to an aromatic group, as well as the presence of a phenolic group. FTIR spectroscopy data showed the presence of hydroxyl $(\mathrm{O}-\mathrm{H})$ in the phenol group at $3320 \mathrm{~cm}^{-1}$, in the carbonyl group $(-\mathrm{C}=\mathrm{O})$ at $1,711 \mathrm{~cm}^{-1}$, and in the aromatic group $(-\mathrm{CH}=\mathrm{CH})$ group at $1,610 \mathrm{~cm}^{-1}$. The $\mathrm{H}-\mathrm{NMR}$ spectrum showed the presence of four two aromatic protons at $\delta_{\mathrm{H}} 6.78(1 \mathrm{H}, s, \mathrm{H}-8)$ and $7.18(1 \mathrm{H}, s, \mathrm{H}-5)$, two alkene protons at $\delta_{\mathrm{H}} 6.17(1 \mathrm{H}, d, J=$ $9.5 \mathrm{~Hz}, \mathrm{H}-2)$ and $7.83(1 \mathrm{H}, d, J=9.5, \mathrm{H}-3)$, and one methoxy group attached to the aromatic group at $\delta_{\mathrm{H}}$ 3.89 ppm. ${ }^{13} \mathrm{C}-\mathrm{NMR}$ data combined with HMQC data in Table 1 shows that compound $\mathbf{1}$ has four quaternary carbons at $\delta_{\mathrm{C}} 56.7112 .1$ (C-10), 146.0 (C-6), 151.9 (C-7), and 151.2 (C-9); one carbonyl group $(-\mathrm{C}=\mathrm{O})$ at $\delta \mathrm{C} 161.3(\mathrm{C}-2)$; and one methoxy group at $\delta_{\mathrm{C}} 56.7$. Based on the HMQC/HMBC correlation data (Table-1 and Fig.-1), supported with LC-ESI-MS data, it can be confirmed that Compound 1 is scopoletin.

Table-1: 1D- and 2D-NMR Data of Compound 1

\begin{tabular}{c|c|c|c}
\hline \multirow{2}{*}{ No. } & \multicolumn{3}{|c}{ Compound $\mathbf{1}$} \\
\cline { 2 - 4 } & $\delta_{\mathrm{H}}(\Sigma \mathrm{H}, \mathrm{m}, J \mathrm{~Hz})$ & HMQC & HMBC \\
\hline 2. & & 161.3 & \\
\hline 3. & $6.17(1 \mathrm{H}, \mathrm{d}, 9.5)$ & 113.3 & $\mathrm{C}-10$ \\
\hline 4. & $7.83(1 \mathrm{H}, \mathrm{d}, 9.5)$ & 144.7 & $\mathrm{C}-2, \mathrm{C}-5, \mathrm{C}-9$ \\
\hline 5. & & 112.1 & \\
\hline 6. & $7.18(1 \mathrm{H}, \mathrm{s})$ & 109.9 & $\mathrm{C}-4, \mathrm{C}-7, \mathrm{C}-9$ \\
\hline 7. & & 146.0 & \\
\hline 8. & & 151.9 & \\
\hline 9. & $6.78(1 \mathrm{H}, \mathrm{s})$ & 103.8 & $\mathrm{C}-6, \mathrm{C}-9, \mathrm{C}-10$ \\
\hline 10. & & 151.2 & \\
\hline 11. & $3.89\left(\mathrm{OCH}_{3}\right)$ & 56.7 & \\
\hline
\end{tabular}


RASĀYAN J. Chem.

Vol. 14 | No. 4 |2420-2427| October- December | 2021

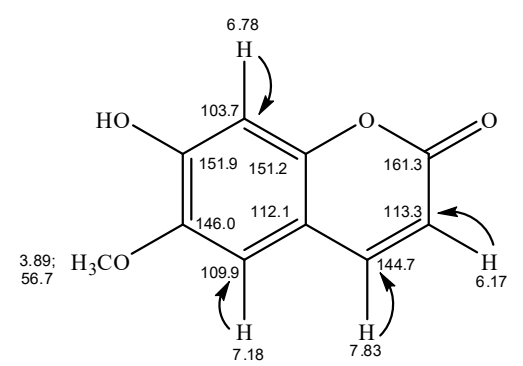

(a)

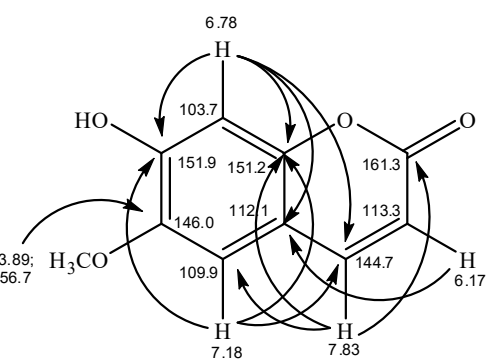

(b)<smiles>COc1cc2ccc(=O)oc2cc1O</smiles>

(c)

Fig.-1: (a) HMQC Correlations, (b) HMBC Correlations, (c) Chemical Structure of Compound 1 (scopoletin)

Compound 2 was obtained as a yellowish-green crystal with a melting point of $345-347{ }^{\circ} \mathrm{C}$. UV-visible absorption spectra of Compound 2 in methanol exhibited two maximum peaks at $\lambda 273$ and $338 \mathrm{~nm}$. Markham (1988) indicated that Compound $\mathbf{2}$ is a flavon type of flavonoid compound. The FTIR spectra showed broadband at $3246 \mathrm{~cm}^{-1}$, indicating the presence of an intermolecular hydroxyl $(-\mathrm{OH})$ stretch vibration. A vibration band at $1,654 \mathrm{~cm}^{-1}$ indicates the existence of a conjugation system between the carbonyl group $(-\mathrm{C}=\mathrm{O})$ with $-\mathrm{C}=\mathrm{C}$ - in $\mathrm{C}-2$ and $\mathrm{C}-3$ positions and a vibration band at $1,570 \mathrm{~cm}^{-1}$ indicates the presence of an aromatic double bond $(\mathrm{C}=\mathrm{C}) .{ }^{1} \mathrm{H}-\mathrm{NMR}$ spectra (Table-2) of Compound 2 indicates the existence of six aromatic protons at $\delta_{\mathrm{H}} 6.15(1 \mathrm{H}, \mathrm{d}, J=1.95 \mathrm{~Hz}, \mathrm{H}-6), 6.44(1 \mathrm{H}, \mathrm{d}, J=1.95 \mathrm{~Hz}, \mathrm{H}-8)$, $7.91(2 \mathrm{H}, \mathrm{d}, J=9.05 \mathrm{~Hz}, \mathrm{H}-2$ ''/H-6'), and $6.90(2 \mathrm{H}, \mathrm{d}, J=9.05 \mathrm{~Hz}, \mathrm{H}-3$ '/H-5'); one proton of heterocyclic pyrane at $\delta_{\mathrm{H}} 6.75(1 \mathrm{H}, \mathrm{s}, \mathrm{H}-3)$; and one proton of a hydrogen bond at $\delta_{\mathrm{H}} 12.94(1 \mathrm{H}, \mathrm{s}) .{ }^{13} \mathrm{C}-\mathrm{NMR}$ spectra (Table-2) indicates the existence of seven carbon methin at $\delta_{\mathrm{C}} 116.0\left(2 \mathrm{C}, \mathrm{C} 3^{\prime} / \mathrm{C}-5^{\prime}\right), 128.5$ (2C, C-2'/C6'), 102.8 (C-3), and $99.0(\mathrm{C}-6), 94.1(\mathrm{C}-8)$; one carbonyl $(-\mathrm{C}=\mathrm{O})$ group at $\delta_{\mathrm{C}} 181.7$; and seven quaternary carbon at $\delta \mathrm{C} 103.6$ (C-10), 121.2 (C-1'), 157.4 (C-9), 161.3 (C-5), 161.5 (C-4'), 163.7 (C-2), and 164.6 (C-7). The correlation between proton peak at $\delta_{\mathrm{H}} 6.75$ with a carbon atom at $\delta \mathrm{C} 163.7,103.6$, and 121.2 indicate that the proton is located at the H-3 position. This indicates that Compound 2 is a flavon. Based on proton-carbon correlations obtained from HMQC and HMBC spectrum data (Table-2 and Fig.-2), supported with UV-visible, FTIR, and LC-ESI-MS data, Compound $\mathbf{2}$ is the flavon compound, apigenin.

Table-2: 1D- and 2D-NMR Data of Compound 2

\begin{tabular}{|c|c|c|c|}
\hline \multirow{2}{*}{ No. } & \multicolumn{3}{|c|}{ Compound $\mathbf{2}$} \\
\hline & $\delta_{\mathrm{H}}(\Sigma \mathrm{H}, \mathrm{m}, J \mathrm{~Hz})$ & HMQC & HMBC \\
\hline 2. & & 163.7 & \\
\hline 3. & $6.75(1 \mathrm{H}, \mathrm{s})$ & 102.8 & $\mathrm{C}-2, \mathrm{C}-10, \mathrm{C}-1{ }^{\prime}$ \\
\hline 4. & & $181.7(-\mathrm{C}=\mathrm{O})$ & \\
\hline 5. & & 161.3 & \\
\hline 6. & $6.15(1 \mathrm{H}, \mathrm{d}, 1.95)$ & 99.0 & C-5, C-7, C-8, C-10 \\
\hline 7. & & 164.6 & \\
\hline 8. & $6.44(1 \mathrm{H}, \mathrm{d}, 1.95)$ & 94.1 & C-6, C-7, C-9, C-10 \\
\hline 9. & & 157.4 & \\
\hline 10. & & 103.6 & \\
\hline $1 '$. & & 121.2 & \\
\hline $2 \%$ ' & $7.91(2 \mathrm{H}, \mathrm{d}, 9.05)$ & $128.5(2 \mathrm{C})$ & C-4' \\
\hline $3{ }^{\prime} / 5^{\prime}$ & $6.90(2 \mathrm{H}, \mathrm{d}, 9.05)$ & $116.0(2 \mathrm{C})$ & C-1', C-4' \\
\hline 4' & & 161.5 & \\
\hline$-\mathrm{OH}$ & $12.94(1 \mathrm{H}, \mathrm{s})$ & & C-5 \\
\hline
\end{tabular}


RASĀYAN J. Chem.

Vol. 14 | No. 4 |2420-2427| October- December | 2021

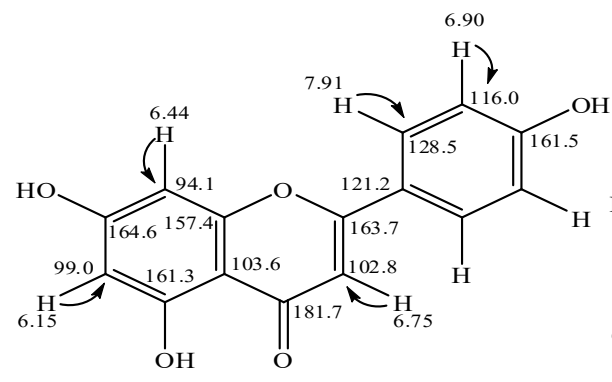

(a)

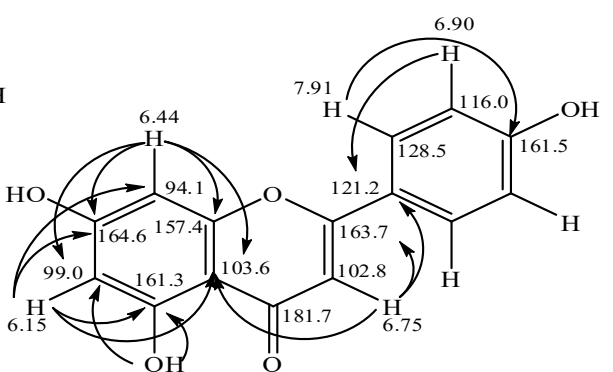

(b)<smiles>O=c1cc(-c2ccc(O)cc2)oc2cc(O)cc(O)c12</smiles>

(c)

Fig.-2: (a) HMQC Correlations, (b) HMBC Correlations, (c) Chemical Structure of Compound 2 (apigenin)

Compound $\mathbf{3}$ was obtained as a white powder with a melting point of $250-252{ }^{\circ} \mathrm{C}$. UV-visible absorption spectra of Compound 3 in methanol exhibited a maximum peak at $\lambda 272$, indicating the presence of a phenolic group. The IR spectra of Compound 3 indicate the existence of hydroxyl (-O-H) group at 3282 $\mathrm{cm}^{-1}$, $-\mathrm{C}-\mathrm{H}$ aromatic rings at $3024,862,711 \mathrm{~cm}^{-1},-\mathrm{C}=\mathrm{C}$-aromatic at $1618,1539 \mathrm{~cm}^{-1}$, carbonyl ester group $(-\mathrm{COOH})$ at $1701 \mathrm{~cm}^{-1}$, and $-\mathrm{C}-\mathrm{O}$ ester group at $1315,1031 \mathrm{~cm}^{-1}$.

${ }^{1} \mathrm{H}-\mathrm{NMR}$ spectra (Table 3 ) of Compound 3 indicate the existence of two symmetrical aromatic protons at $\delta_{\mathrm{H}} 7.05(2 \mathrm{H}, \mathrm{s}) .{ }^{13} \mathrm{C}-\mathrm{NMR}$ spectra (Table 3 ) showed the existence of two symmetrical carbon methin at $\delta_{\mathrm{C}}$ $110.4(2 \mathrm{C}, \mathrm{C} 3 / \mathrm{C}-7)$, three phenolic carbon atoms at $\delta_{\mathrm{C}} 139.7(\mathrm{C}-5)$ and $146.5(2 \mathrm{C}, \mathrm{C}-4 / \mathrm{C}-6)$, one quaternary carbon atom at $\delta_{\mathrm{C}} 122.0$, and carbonyl $(-\mathrm{C}=\mathrm{O})$ at $\delta_{\mathrm{C}} 170.5$. Based on the proton-carbon correlations obtained from HMQC and HMBC spectrum data (Table-3 and Fig.-3), supported with UVvisible, FTIR, and LC-ESI-MS data, indicated Compound $\mathbf{3}$ is gallic acid.

Table-3: 1D- and 2D-NMR Data of Compound 3

\begin{tabular}{c|c|c|c}
\hline \multirow{2}{*}{ No. } & \multicolumn{3}{|c}{ Compound 3 } \\
\cline { 2 - 4 } & $\delta_{\mathrm{H}}(\Sigma \mathrm{H}, \mathrm{m}, J \mathrm{~Hz})$ & HMQC & HMBC \\
\hline 1. & & $170.5(-\mathrm{C}=\mathrm{O})$ & \\
\hline 2. & & 122.0 & $\mathrm{C}-5, \mathrm{C}-4 / \mathrm{C}-6, \mathrm{C}-1$ \\
\hline $3 / 7$. & $7.06(2 \mathrm{H}, \mathrm{s})$ & $110.4(2 \mathrm{C})$ & \\
\hline $4 / 6$. & & $146.5(2 \mathrm{C})$ & \\
\hline 5 & & 139.7 & \\
\hline
\end{tabular}

The anti-diabetic activity of isolated compounds was evaluated against $\alpha$-glucosidase enzyme using the methods developed by Dewi ${ }^{30}$, where quercetin, a plant polyphenol compound that has many biological activities such as anti-inflammatory, anticancer, antidiabetic, neuroprotective, anti-allergic and antioxidant, was used as positive control. ${ }^{31-32}$ The results show that all the isolated compounds have lower inhibitory activity against $\alpha$-glucosidase enzyme, compared to quercetin $\left(\mathrm{IC}_{50} 5.05 \mu \mathrm{g} / \mathrm{ml}\right)$, with the inhibitory activity $\left(\mathrm{IC}_{50}\right)$ of Compounds $\mathbf{1 - 3}$ at $91.73,28.28$, and $197.22 \mu \mathrm{g} / \mathrm{ml}$, respectively (Table-4).

\section{CONCLUSION}

Our continuous project of drug discovery from Indonesian natural product resources has led to the isolation of three secondary metabolite compounds, namely, (1) scopoletin, (2) apigenin, and (3) gallic acid, from the leaf of Macaranga magna Turrill. Their biological activity of $\alpha$-glucosidase inhibitory activity was lower compared to quercetin as a positive control ( $\mathrm{IC}_{50} 5.05 \mu \mathrm{g} / \mathrm{ml}$ ). Apigenin, a flavonoid 
RASĀYAN J. Chem.

Vol. 14 | No. 4 |2420-2427| October- December | 2021

compound, and quercetin, showed the highest $\alpha$-glucosidase inhibitory activity with an $\mathrm{IC}_{50}$ value of $28.28 \mu \mathrm{g} / \mathrm{mL}$, compared to scopoletin and gallic acid with $\mathrm{IC}_{50}$ values of 91.73 and $197.22 \mu \mathrm{g} / \mathrm{mL}$, respectively. This is first report of isolation of scopoletin, apigenin, and gallic acid from Macaranga magna Turrill.

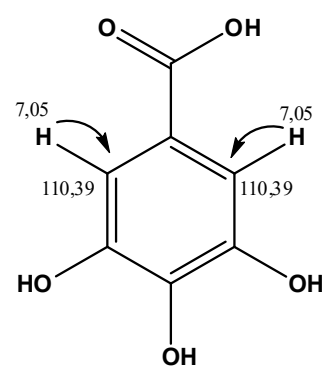

(a)

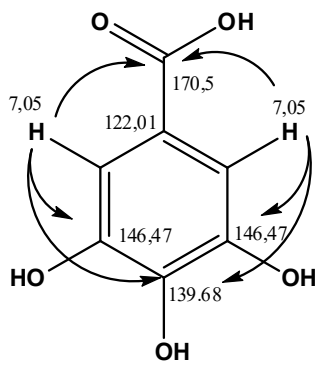

(b)<smiles>O=C(O)c1ccc(O)c(O)c1O</smiles>

(c)

Fig.-3: (a) HMQC Correlations, (b) HMBC Correlations, (c) Chemical Structure of Compound 3 (Gallic Acid)

Table-4: $\alpha$-glucosidase Inhibitory Activity

\begin{tabular}{c|l|c|c|c|c}
\hline No. & Sample & Absorbance & $\begin{array}{c}\text { Concentrations } \\
(\mu \mathrm{g} / \mathrm{mL})\end{array}$ & $\begin{array}{c}\text { Inhibition } \\
(\%)\end{array}$ & $\mathrm{IC}_{50}(\mu \mathrm{g} / \mathrm{mL})$ \\
\hline & Blank & 0.1195 & & & \\
\hline 1 & Quercetin & 0.0717 & 10 & 94.00 & 5.05 \\
& & 0.3501 & 7.5 & 70.69 & \\
& & 0.6112 & 5 & 48.83 & \\
\hline 2 & Compound 1 & 0.8540 & 2.5 & 28.51 & 91.73 \\
& & 0.5105 & 200 & 51.14 & \\
& & 0.8045 & 100 & 32.65 & \\
\hline 3 & Compound 2 & 0.9300 & 50 & 22.14 & \\
& & 0.5940 & 25 & 89.80 & \\
& & 1.0157 & 25 & 50.27 & 19.97 \\
& & 1.0472 & 12.5 & 12.33 & \\
\hline 4 & Compound 3 & 0.5909 & 200 & 50.53 & \\
& & 0.8525 & 100 & 28.63 & \\
& & 0.9342 & 50 & 21.79 & \\
& & 1.0169 & 25 & 14.87 & \\
& & 1.0899 & 10 & 8.76 & \\
\hline
\end{tabular}

\section{ACKNOWLEDGEMENT}

The authors would like to thank the Indonesian Institute of Sciences (LIPI) for their 'by-research program'.

\section{REFERENCES}

1. Yuliet, E.Y Sukandar, K. Budipramana, I.K. Adnyana, Rasayan Journal of Chemistry, 13(2), 826 (2020), https://doi.org/10.31788/RJC.2020.1325607

2. S. Fajriah, Megawati, A. Darmawan, The Journal of Tropical Life Science, 6(1), 7(2016) 
RASĀYAN J. Chem.

Vol. 14 | No. 4 |2420-2427| October- December | 2021

3. A. Khatun, M. Rahman, S. Kabir, World Journal of Pharmaceutical Research, 3(10), 172(2014)

4. J.J. Magadula, Journal of Medicinal Plant Research, 8(12), 489(2014), https://doi.org/10.5897/JMPR2014.5396

5. T.M.H. Doan, T.L. Nguyen, T.T.V. Trinh, V.N. Vu, T.D. Phi, M. Litaudon, F. Roussi, V.M. Chau, V.C. Pham, Journal of Analytical Methods in Chemistry, 2019, 1 (2019), https://doi.org/10.1155/2019/2917032

6. T.Y. Lim, Y.Y. Lim, C.M. Yule, Journal of Tropical Forest Science, 26(1), 134 (2014).

7. G. Primahana, A. Darmawan, The Journal of Pure and Applied Chemistry Research, 6(1), 22 (2017), https://doi.org/10.21776/ub.jpacr.2017.006.01.298

8. P. Segun, M. Gbadebo, M. Adebowale, C. Olufolabo, A.F. Jaiyesimi, Acta Pharmaceutica Sciencia, 57(4), 93 (2019), https://doi.org/10.23893/1307-2080.APS.05726

9. E. Asante-Kwatia, Y. Jibira, A.Y. Mensah, D. Osei-Sarfoh, Discovery Phytomedicine, 6(3), 130 (2019), https://doi.org/10.15562/phytomedicine.2019.104

10. L.T.N. Vu, L.T. Anh, N.T. Cuc, N.X. Nhiem, B.H. Tai, P.V. Kiem, M. Litaudon, T.D. Thach, C.V. Minh, H.D.T. Mai, P.V. Cuong, Natural Product Research,35(13), 2123(2019), https://doi.org/10.1080/14786419.2019.1662007

11. I. Zakaria, N. Ahmat, R. Ahmad, F.M. Jaafar, N. Ab. Ghani, S. Khamis, World Applied Sciences Journal, 9(9), 1003 (2010).

12. C.Y. Ragasa, J. de Jesus, Research Journal of Pharmaceutical, Biological and Chemical Sciences, 5(3), $701(2014)$

13. M. Tanjung, E.H. Hakim, D. Mujahidin, M. Hanafi, Y.M. Syah, Journal of Asian Natural Products Research, 11(11), 929 (2009), https://doi.org/10.1080/10286020903302315

14. D.S. Yang, J.G. Wei, W.B. Peng, S.M. Wang, C. Sun, Y.P. Yang, K.C. Liu, X.L. Li, Fitoterapia, 99 , 261(2014), https://doi.org/10.1016/j.fitote.2014.10.003

15. D.S. Yang, Z.L. Li, W.B. Peng, Y.P. Yang, X. Wang, K.C. Liu, X.L. Li, W.L. Xiao, Fitoterapia, 103, 165(2015), https://doi.org/10.1016/j.fitote.2015.04.001

16. A. Darmawan, S. Kosela, L. B.S. Kardono, Y.M. Syah, Journal of Applied Pharmaceutical Science, 2(12), 175(2012), https://doi.org/10.7324/JAPS.2012.21231

17. M.S. Fareza, Y.M. Syah, D. Mujahidin, L.D. Juliawaty, I. Kurniasih, Z. Naturforsch, 69c, 375 (2014), https://doi.org/10.5560/ZNC.2014-0066

18. E. Marliana, W. Astuti, K. Kosala, R. Hairani, T.S. Tjahjandarie, M. Tanjung, Asian Journal of Chemistry, 30(4), 795 (2018), https://doi.org/10.14233/ajchem.2018.21004

19. E. Marliana, R. Ruga, R Hairani, T.S. Tjahjandarie, M. Tanjung, Journal of Physics: Conference Series, Conf. Series, 1277 (2019), 012014(2019), https://doi.org/10.1088/17426596/1277/1/012014

20. J.H. Lee, Y.G. Kim, S.K. Khadke, A. Yamano, J.T. Woo, J. Lee, Phytomedicine, 63,(2019), https://doi.org/10.1016/i.phymed.2019.153033

21. B.J. Yoder, S. Cao, A. Norris, J.S. Miller, F. Ratovoson, J. Razafitsalama, R. Andriantsiferana, V.E. Rasamison, G.I. Kingston, Journal of Natural Products, 70(3), 342(2007), https://doi.org/10.1021/np060484y

22. T. Péresse, G. Jézéquel, P.M. Allard, V.C. Pham, T.M.H. Doan, F. Blanchard, J. Bignon, H. Lévaique, J.L. Wolfender, M. Litaudon, F. Roussi. Journal of Natural Products, 80(10), 2684 (2017), https://doi.org/10.1021/acs.jnatprod.7b00409

23. J.A. Beutler, J. Jato, G.M. Cragg, M.R. Boyd. Natural Product Letters, 14(5), 399(2000), https://doi.org/10.1080/10575630008043774

24. H.D.T. Mai, T.P. Toan, G.T. Huu, T.N. Le, V.T.K. Oanh, N.T.M. Hang, H.T. Thu, V.M. Chau, M. Litaudon, V.C. Pham, Natural Product Research, (2019), https://doi.org/10.1080/14786419.2019.1587425

25. N.S. Aminah, A.N. Kristanti, M. Tanjung, Journal of Chemical and Pharmaceutical Research, 6(6), 688(2014). 
RASĀYAN J. Chem.

Vol. 14 | No. 4 |2420-2427| October- December | 2021

26. E.T. Arung, J.R. Sinamabela, E. Rosamah, I.W. Kusuma, H. Kuspradini, A.E. Alam, Y. Amen, H. Tanaka, D. Satria, K. Shimizu, H. Ishikawa, Natural Product Communications, July 2019, 1 (2019), https://doi.org/10.1177/1934578X19867192

27. A. Ogundajo, B. Okeleye, A.O. Ashafa, Asian Pacific Journal of Tropical Biomedicine, 7(7), 654 (2017), https://doi.org/10.1016/j.apjtb.2017.06.014

28. W. Aligita, S. Muhsinin, E. Susilawati, Dahlia, D.S. Pratiwi, D. Aprilliani, A. Artarini, I.K. Adnyana, Rasayan Journal of Chemistry, 12(1), 157(2019), https://doi.org/10.31788/RJC.2019.1215059

29. Minarti, A.H. Cahyana, A. Darmawan, Proceedings of the 5th International Symposium on Applied Chemistry 2019, AIP Conf. Proc. 2175, (2019), Jakarta, Indonesia, 020029-1-020029-9, https://doi.org/10.1063/1.5134593

30. R.T. Dewi, A. Darmawan, H. Mulyani., P.D.N. Lotulung, Minarti, Megawati, Malaysia Journal of Science, 37(1), 70 (2018), https://doi.org/10.22452/mis.vol37no1.5

31. D. Sukandar, S. Nurbayti, T. Rudiana, T.W. Husna, Indonesian Journal of Applied Chemistry, 19(1), 11(2017).

32. M. Bule, A. Abdurahman, S. Nikfar, M. Abdollahi, M. Amini, Food and Chemical Toxicology, 125, 496(2019), https://doi.org/10.1016/j.fct.2019.01.037

[RJC-6290/2020] 